\title{
DETERMINANTS OF COMMERCIAL PRODUCTION OF WHEAT IN NIGERIA: A CASE STUDY OF BAKURA LOCAL GOVERNMENT AREA, ZAMFARA STATE
}

\author{
A. Falola ${ }^{1}$; B. A. Achem ${ }^{2}$, W. O. Oloyede ${ }^{1}$, G. O. Olawuyi ${ }^{1}$ \\ ${ }^{1}$ Department of Agricultural Economics and Farm Management, University of Ilorin, Ilorin, \\ Kwara State, Nigeria \\ ${ }^{2}$ National Centre for Agricultural Mechanization, Ilorin, Nigeria
}

\begin{abstract}
In Nigeria, wheat is a crop of both household and industrial importance. However, despite its good climatic and edaphic conditions, Nigeria still relies on massive wheat importation. This study therefore examined the factors influencing commercial production of wheat in Bakura Local Government Area (a wheat zone) of Zamfara State, Nigeria. Primary data were obtained from 210 wheat farming households and analyzed with descriptive statistics, household commercialization index (HCI) and tobit regression. The results showed that the average HCI was $54.7 \%$, implying that there is a gap of $45.3 \%$ for the farmers to attain full commercialization level. Farm size, fertilizer, credit, access to improved varieties, age of household head, using man-power as the only source of labour for cultivation and non-farm income were found to significantly influence household commercialization of wheat production. The major constraints faced by the household vis-a-vis wheat production were low output price, inadequate land, lack of production inputs, high cost of inputs, transportation problem, inadequate credit facilities and diseases/pests. This study therefore recommends provision of inputs and credit to farmers, encouraging the youth to actively participate in wheat farming, encouraging wheat farmers through price support programmes as well as expanding farmland put to wheat cultivation.
\end{abstract}

Key words: Wheat importation, Household commercialization index, Factors, Constraints

\section{INTRODUCTION}

Globally, wheat (Triticum aestivum) is an important industrial and food grain. It ranks second among the most important cereal crops in the world, after rice (1). It is the most important cereals traded on international markets (2). In Nigeria, wheat is consumed in one form or the other in virtually every home, restaurants and hotels throughout the country. Besides, the crop is the main raw material in the Nigeria flour mills. Its flour is used for making bread, confectionaries, biscuits and other snacks. The offal (residue) is used in the feed-mills in compounding livestock feeds (3). Nigeria is the most populous country in Africa. It constitutes about half of West Africa's population and has a population of about 178.5

\footnotetext{
*Correspondence to: A. Falola, Department of Agricultural Economics and Farm Management, University of Ilorin, P.M.B. 1515, Ilorin, Kwara State, Nigeria, falolaabraham@yahoo.com; falola.a@unilorin.edu.ng, Phone No: +2348032885450, +2348154557502
}

million people (4). Agriculture is the mainstay of the country contributing about $42 \%$ of gross domestic product (GDP) (5), providing employment to about $70 \%$ of the labour force (IFAD, 2012), accounting for over $70 \%$ of the non-oil exports and perhaps most importantly, providing over $80 \%$ of the food needs of the country $(3,6)$. Nigeria has good ecological and edaphic conditions that can favour wheat production. Notwithstanding, achieving selfsufficiency in wheat production still remains a challenge. Since indepedence (1960), Nigeria has been depending on wheat importation to meet the domestic consumption. For instance, statistics show that from 1990 to 2013, the average production of wheat in Nigeria was about 81,904 metric tonnes while the average importation of wheat in the country was $2,193,566$ metric tonnes within the same period (7).

In an attempt to make Nigeria self-sufficient in wheat production, several measures were put in place by the federal government of Nigeria. 
These measures include launching of several agricultural programmes and establishing several institutes aimed at stimulating interest in local production of wheat. Some of these were the National Cereal Research Institute (NCRI) in 1974, National Seed Service (NSS) in 1975, Operation Feed the Nation (OFN) in 1976, Basin Development Authority (RDBA), Agricultural Development Projects (ADP) (1975), National Grain Production Programmes (NGPP) and Accelerated Wheat Production Programme (AWPP), just to mention but a few. Also, the federal government of Nigeria, at different times, raised the tariff on wheat importation in order to protect local producers against massive imports of wheat. Despite the various interventions, however, there is still a wide gap between domestic demand and supply of wheat in the country. This is partly because wheat production in many parts of the country has remained at subsistence-oriented level despite its comparative advantage of producing in large quantity for commercialization.

Agricultural commercialization may be defined as the proportion of agricultural production that is marketed. It involves the deliberate action on the part of agricultural producer to use factors of production in a way that a greater part of the crops produced is for exchanged or sale $(8,9)$. Commercialization of agriculture also involves a transition from subsistence-oriented to increasingly marketoriented patterns of production and input use among farming households. The underlying premise is that markets allow households to increase their incomes by producing that which provide the highest returns to land and labour and then use the cash to buy household consumption items, rather than being constrained to produce all the various goods that the household needs to consume $(10,11$, $12)$.

Formulating sound policies on bridging the gap between domestic demand and supply of wheat in Nigeria and making it self-reliant in wheat production requires a deep knowledge about the current commercialization level among wheat farmers and the factors responsible for these levels. This can also be achieved when the challenges confronting household commercialization of the crop are addressed. From the foregoing, this study examines the determinants of household commercialization of wheat production in Bakura Local Government Area of Zamfara State, which is a "wheat zone" in Nigeria. The specific objectives were to (i) describe the socio-economic characteristics of wheat farmers in the area;

(ii) determine the household commercialization level of wheat production in the study area;

(iii) identify factors affecting household commercialization of wheat production; and

(iv) identify the constraints to wheat production in the study area.

\section{METHODOLOGY}

The study was conducted in Bakura Local Government Area (LGA) of Zamfara State, Nigeria. The choice of the LGA was premised on the fact that it is one of the leading wheatproducing areas (wheat zones) in the country.

The data for the study were mainly obtained from primary sources. The sampling frame was made up of the wheat farming households in the study area. A two-stage sampling technique was used for the study. The first stage involved a random selection of thirteen (13) farming communities from the LGA. Prior information from the LGA revealed that there were 454 wheat farming households across the selected communities. A significant proportion of the population was desired, so, a finite population correction factor was applied. Thus, the minimum sample size to be used was determined using the formular:

$\mathrm{n}=\mathrm{N} * \mathrm{X} /(\mathrm{X}+\mathrm{N}-1)$

where,

$\mathrm{X}=\mathrm{Z}_{\alpha / 2}{ }^{2} * \mathrm{p} *(1-\mathrm{p}) / \mathrm{MOE}^{2}$

and $Z_{\alpha / 2}$ is the critical value of the normal distribution at $\alpha / 2$. A confidence level of $95 \%$ was used for the study, thus, $\alpha$ is 0.05 and the critical value is 1.96. MOE is the margin of error, $\mathrm{p}$ is the sample proportion, and $\mathrm{N}$ is the population size $(13,14)$. This gives a minimum sample size of 209 respondents. Thus, a minimum of 209 respondents were needed for the study.

The second stage was a random selection 210 wheat farming households across the communities using probability proportion to size technique (Table 1). The data for this study were collected with the aid of a wellstructured questionnaire augmented with personal interview with the farming households.

The data were analysed with descriptive statistics, household commercialization index and tobit regression. Descriptive statistics such as measures of central tendency and percentages were used to examine the socio-economic characteristics of the farmers. It was also used to analyze the barriers to commercial production of wheat by the farmers. 
FALOLA A., et al.

Table 1. Sampling design for the study

\begin{tabular}{llll}
\hline Communities & $\begin{array}{l}\text { No of wheat farming } \\
\text { households }\end{array}$ & No of households selected & Percentage \\
\hline Birintudu & 207 & 96 & 45.7 \\
Ware Dantse & 11 & 5 & 2.4 \\
Gidan Dikko & 15 & 7 & 3.3 \\
Maddaci & 19 & 9 & 4.3 \\
Maitako & 37 & 17 & 8.1 \\
Rini & 22 & 10 & 4.8 \\
Talaye & 11 & 5 & 2.4 \\
Tungar Fadama & 28 & 13 & 6.2 \\
Tungar Kalgo & 13 & 6 & 2.9 \\
Tungar Maiburtu & 9 & 4 & 1.9 \\
Yabawa & 11 & 5 & 2.4 \\
Yardala & 50 & 23 & 11 \\
Yarkofoji & 22 & 10 & 4.8 \\
Total & 454 & 210 & 100.0 \\
\hline
\end{tabular}

Source: Field Survey, 2015

Household commercialization index was used to determine the extent to which wheat production was market-oriented in the study area. This was evaluated as the ratio of gross value of farm output to the value sold $(9,12$, $15)$. The model is specified as

Household commercialization index $=\frac{\text { Gross value of wheat sold }}{\text { Gross value of wheat produced }} X 100 \% \ldots \ldots \ldots \ldots$

The value ranges from 0 to $100 \%$. The closer the index is to 100 the higher the degree of commercialization. A value of zero is an indication that the farmer is operating under subsistence agriculture. The closer HCI is to 100 the higher the degree of commercialization $(12,15)$.

Factors influencing household commercialization of wheat production were ascertained with tobit regression model. The tobit regression is a statistical model used to describe the relationship between a nonnegative dependent variable $\mathrm{y}_{i}$ and an independent variable (vector) $\mathrm{x}_{i}$. This explained variable linearly depends on the explanatory variables via a parameter which determines the relationship between the independent variable and the latent variable. The model has a normally distributed error term to capture random influences on the relationship. The observable variable is defined to be equal to the latent variable whenever the latent variable is above zero and zero otherwise. The choice of the model was based on the fact that some of the results of household commercialization indices of the respondents were zeros; the model was censored at zero.

The implicit form of the Tobit regression is given by

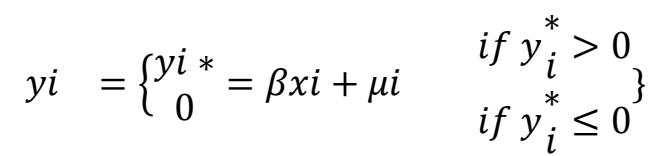

Where the explicit form of the model is as follows;

$y_{i}^{*}=\beta \mathrm{X}_{1}+\beta \mathrm{X}_{2}+\beta \mathrm{X}_{3}+\beta \mathrm{X}_{4}+\beta \mathrm{X}_{5}+\beta \mathrm{X}_{6}+\beta \mathrm{X}_{7}+\beta \mathrm{X}_{8}$

$+\beta \mathrm{X}_{9}+\beta \mathrm{X}_{10}+\beta \mathrm{X}_{11}+\beta \mathrm{X}_{12}+\beta \mathrm{X}_{13}+\beta \mathrm{X}_{14}+\mathrm{U}$

Where, $Y_{i}=$ Household commercialization index of $i$ th household; $\mathrm{X}_{1}=$ Sex of the household head ( 1 if male, 0 if otherwise); $X_{2}=$ Age of household head (Years); $\mathrm{X}_{3}=$ Household size (Number of household members); $\quad \mathrm{X}_{4}=$ Educational attainment (Number of successful years spent in school); $\mathrm{X}_{5}=$ Use of machinery for wheat production (rated as 1 if used, 0 if otherwise); $\mathrm{X}_{6}=$ Fertilizer $(\mathrm{kg}) ; \quad \mathrm{X}_{7}=$ Extension services (number of extension contact); $\mathrm{X}_{8}=$ Access to credit ( 1 if yes, 0 if otherwise); $\mathrm{X}_{9}=$ Farm size (hectares); $\mathrm{X}_{10}=$ Non-farm income (naira); $\mathrm{X}_{11}=$ Farming experience (years); $\mathrm{X}_{12}=$ Cooperative membership $(1$ for membership, 0 if otherwise); $\mathrm{X}_{13}=$ Pesticides (litres); $\beta=$ Coefficient to be estimated; and $\mathrm{U}=$ Error term.

\section{RESULTS AND DISCUSSION SOCIO-ECONOMIC CHARACTERISTICS OF THE FARMING HOUSEHOLDS}

Table 2 shows the socio-economic characteristics of the farming households. The 
FALOLA A., et al.

majority of the respondents were male. This indicates the dominance of the male among the farmers. About $70.5 \%$ of the respondents were within the age range of $30-50$ years. Further analysis revealed that the mean age of the respondents was 42 years. This suggests that the farmers were still in their active age. It is noteworthy, however, that just $10.5 \%$ of the respondents were not older than 30 years, which is the official age limit recognized by the National Youth Service Corps (NYSC) in Nigeria for an individual to be referred to as being a youth. This might be due to the high level of apathy exhibited by the youth to agriculture (16-20).

Table 2. Socio-economic characteristics of the respondents $(N=210)$

\begin{tabular}{|c|c|c|c|}
\hline Variables & Category & Frequency & Percentage \\
\hline \multirow[t]{2}{*}{ Gender } & Male & 205 & 97.6 \\
\hline & Female & 5 & 2.4 \\
\hline \multirow[t]{5}{*}{ Age(years) } & $\leq 30$ & 22 & 10.5 \\
\hline & $31-40$ & 74 & 35.2 \\
\hline & $41-50$ & 52 & 24.8 \\
\hline & $51-60$ & 54 & 25.7 \\
\hline & $>60$ & 8 & 3.8 \\
\hline \multirow[t]{4}{*}{ Marital status } & Married & 196 & 87.4 \\
\hline & Single & 4 & 7.9 \\
\hline & Divorced & 3 & 1.4 \\
\hline & Widowed & 7 & 3.3 \\
\hline \multirow[t]{4}{*}{ Household size } & $\leq 5$ & 12 & 5.7 \\
\hline & $6-10$ & 118 & 56.2 \\
\hline & $11-15$ & 75 & 35.7 \\
\hline & $>15$ & 5 & 2.4 \\
\hline \multirow{4}{*}{$\begin{array}{l}\text { Educational level of } \\
\text { household head }\end{array}$} & No formal education & 145 & 69.1 \\
\hline & Primary education & 39 & 18.6 \\
\hline & Secondary education & 23 & 11.0 \\
\hline & Tertiary education & 3 & 1.4 \\
\hline \multirow[t]{3}{*}{ Primary occupation } & Farming & 180 & 85.8 \\
\hline & Non - formal & 6 & 2.9 \\
\hline & Formal & 24 & 11.4 \\
\hline \multirow[t]{6}{*}{ Source of farmland } & Inheritance & 128 & 61.0 \\
\hline & Purchase & 29 & 13.8 \\
\hline & Lease & 38 & 18.1 \\
\hline & Government owned & 4 & 1.9 \\
\hline & Communally owned & 2 & 1.0 \\
\hline & Borrowing & 9 & 4.3 \\
\hline \multirow[t]{4}{*}{ Farm size (ha) } & $\leq 5.00$ & 157 & 74.8 \\
\hline & $5.01-10.0$ & 39 & 18.6 \\
\hline & $10.01-15.0$ & 12 & 5.7 \\
\hline & $>15.0$ & 2 & 1.0 \\
\hline \multirow{5}{*}{$\begin{array}{l}\text { Farming experience } \\
\text { (years) }\end{array}$} & $5-10$ & 147 & 70.0 \\
\hline & $10-15$ & 31 & 14.8 \\
\hline & $15-20$ & 16 & 7.6 \\
\hline & $20-25$ & 6 & 2.9 \\
\hline & $>25$ & 10 & 4.8 \\
\hline \multirow[t]{2}{*}{ Farmers association } & Yes & 89 & 42.4 \\
\hline & No & 121 & 57.6 \\
\hline \multirow[t]{3}{*}{ Main source of inputs } & Own farm & 135 & 64.2 \\
\hline & Open market & 42 & 20.0 \\
\hline & Government agencies & 33 & 15.7 \\
\hline \multirow[t]{2}{*}{ Access to extension } & Yes & 87 & 41.4 \\
\hline & No & 123 & 58.6 \\
\hline
\end{tabular}

Source: Field Survey, 2015

Most $(87.4 \%)$ of the household heads were married. The household size of the respondents ranged from one to seventeen members. The modal group was 6-10 persons, accounting for $56.2 \%$ of the respondents. Further analysis revealed that the mean household size of the respondents was eight persons. These results likely suggest that wheat farming was a means 
of catering for the family in the study area. A large proportion $(69.1 \%)$ of the farmers had no formal education. Only $11 \%$ had secondary education while just $1.4 \%$ had tertiary education. This scenario might result from the preference for white collar jobs by welleducated individuals, with negligence to agriculture, especially in developing countries like Nigeria $(19,20)$.

The main occupation of the respondents was farming and most of them obtained their farmland through inheritance and operate on an average of about 4.75 hectares. The mean farming experience of the respondents was about nine years, indicating that wheat production is an age-long venture in the study area. The majority of the respondents sourced their farm inputs from own farm (previous harvest).

\section{ANALYSIS OF LEVEL OF COMMERCIALIZATION OF WHEAT PRODUCTION BY THE FARMING HOUSEHOLDS}

Table 3 shows the summary of the wheat produced, consumed or sold by a typical farming household in the study area. The mean quantity of wheat produced was 9.63 tonnes, out of which 4.36 tonnes was consumed and 5.27 tonnes was sold. It is noteworthy that one tonne of wheat was sold for $\$ 95,000$ in the study area (1 US Dollar= $\$ 315.25$ ). Thus, the values of wheat produced, consumed and sold by the farmers were $\$ 14,850, \$ 414,200$ and $\$ 500,650$ respectively $(1 \quad$ US Dollar= $\$ 315.25$ ).

Table 3. Breakdown of wheat produced, consumed and sold by the farming households

\begin{tabular}{lll}
\hline Variable & Mean quantity (MT) & Value (\$) \\
\hline Quantity produced & 3.93 & 931,410 \\
Quantity consumed (as food, gifts, or stored) & 1.78 & 421,860 \\
Quantity sold & 2.15 & 509,550 \\
\hline
\end{tabular}

Note: 1 US Dollar = $\$ 315.25$; Source: Field survey, 2015

Table 4 shows the distribution of the respondents according to their HCIs. The HCIs of the respondents ranged from $0-89.7 \%$. Further analysis revealed that those whose HCIs were $0 \%$ were $6.2 \%$, implying that such farmers produced for household consumption (as food, gifts or storage) only. The modal group were those whose HCIs indices were between $50-60 \%$. The mean household commercialization index of the farmers was $54.7 \%$. Analysis of the results also revealed that those whose commercialization indices fell below this average were $35.3 \%$ while $64.7 \%$ of the farmers had their commercialization indices greater than or equal to this average. The mean household commercialization index $(54.7 \%)$ obtained in the study area implies that the wheat farmers still have a gap of $45.3 \%(100-54.7) \%$ to achieve full commercialization in wheat production. The implication of these results is that only almost half $(45.3 \%)$ of the wheat produced by the farming households is used for household consumption while the remainder $(54.7 \%)$ is being 'competed for' by other members of the public and wheat-based industries.

Table 4. Distribution of the respondents by household commercialization indices

\begin{tabular}{lllllc}
\hline $\begin{array}{l}\text { Commercialization } \\
\text { indices }\end{array}$ & No of respondents & Percentage & Minimum & Maximum & Mean \\
\hline$\leq 30.0$ & 53 & 25.2 & 0.0 & 30.0 & 18.3 \\
$30.1-40.0$ & 8 & 3.8 & 33.3 & 40.0 & 36.6 \\
$40.1-50.0$ & 9 & 4.3 & 40.9 & 49.8 & 46.4 \\
$50.1-60.0$ & 77 & 36.7 & 52.6 & 60.0 & 56.8 \\
$60.1-70.0$ & 14 & 6.7 & 62.5 & 70.0 & 66.8 \\
$70.1-80.0$ & 22 & 10.5 & 71.4 & 78.9 & 72.7 \\
$>80.0$ & 27 & 12.9 & 81.8 & 89.7 & 85.2 \\
Sample & 210 & 100 & 0.0 & 89.7 & 54.7 \\
\hline
\end{tabular}

Source: Field survey, 2015

FACTORS INFLUENCING

COMMERCIALIZATION OF WHEAT PRODUCTION IN THE STUDY AREA

Table 5 shows that result of the regression analysis on factors affecting household commercialization of wheat production in the study area. The results of show the age of household head had a negative coefficient and were statistically significant $(\mathrm{p}<0.05)$. This implies that the older a household head is, the less the degree of producing wheat at commercial level and vice versa. This could 
FALOLA A., et al.

result from the fact that the more a farmer grows older, the less energetic or innovative he/she is likely to become. Other things being equal, young farmers usually have more physical strength to carry out agricultural production activities than their old counterparts (21-23). Similarly, the youth are more innovative and can adopt relevant agricultural practices more easily than their older counterparts $(12,21)$. These could explain the negative relationship that existed between the age of the household heads and their commercialization level.

Table 5. Factors influencing commercialization of wheat production in the study area

\begin{tabular}{lllll}
\hline Variables & Coefficient & Standard error & $\mathbf{t}$ value & $\mathbf{p}>[\mathbf{t}]$ \\
\hline Constant & $56.64883^{* *}$ & 27.81658 & 2.04 & 0.043 \\
Sex & 14.623 & 20.70011 & 0.71 & 0.481 \\
Age of household head & $-2.560821^{* * *}$ & 1.290677 & -1.98 & 0.049 \\
Household size & -0.0867267 & 0.352143 & -0.25 & 0.806 \\
Education attainment & 0.0209929 & 0.0194571 & 1.08 & 0.282 \\
Use of farm machinery & $9.036827^{*}$ & 4.678939 & 1.93 & 0.055 \\
Fertilizer & $1.0536021^{* *}$ & 0.4874104 & 2.16 & 0.032 \\
Extension services & -1.578952 & 2.602031 & -0.61 & 0.545 \\
Access to credit & $6.688109^{* * *}$ & 2.483297 & 2.69 & 0.008 \\
Farm size & $24.35255^{* * *}$ & 7.38726 & 3.30 & 0.001 \\
Non-farm income & $-0.0006034^{*}$ & 0.0003387 & -1.78 & 0.076 \\
Farming experience & -6.770214 & 4.297533 & -1.58 & 0.117 \\
Membership of farmers' association & 3.594723 & 2.830318 & 1.27 & 0.206 \\
Access to improved varieties & $7.118932^{* * *}$ & 1.117372 & 6.37 & 0.000 \\
Pesticides & 4.391242 & 4.663003 & 0.94 & 0.347 \\
LR chi 2(14) $=64.16$ & & & & \\
McFadden's pseudo R ${ }^{2}=0.3053$ & & & & \\
Log likelihood $=-877.92576$ & & & & \\
Prob $>$ chi2 $=0.0000$ & & & & \\
\hline
\end{tabular}

Note:*** significant at $1 \% * *$ significant at 5\%* significant at 10\%; Source: Field survey, 2015

The use of machinery in wheat production was positively significant $(\mathrm{p}<0.10)$. This implies that farming households that used farm machinery had more wheat for the market than those who did not. This is logical, as the use of machinery has the tendency of improving agricultural productivity thereby increasing the amount of output meant for the market (24-26).

Farm size had a positive coefficient and was statistically significant $(\mathrm{p}<0.01)$. This is in line with a priori expectation. The implication is that the farmers who had more farmland under cultivation produced more wheat for the market. On the other hand, limited access to land could reduce farmer's ability to engage in commercial agricultural production.

The relationship between access to credit and household commercialization was positive and was also significant at $1 \%$. This result indicates that the more the farmer acquires credit the more the production is oriented towards market. On the other hand, limited access to credit could reduce the ability of farmers to engage in market-oriented production. Also, the use of fertilizer had a positive (significant) influence $\quad(\mathrm{p}<0.05)$ on household commercialization of wheat production in the study area. The implication of this that farmers who use more fertilizer produce more and had more wheat for sale than those who do not.
However, non-farm income had a negative but significant coefficient $(p<0.1)$, implying that it has a negative effect on level of commercialization of wheat production by the farmers. One would expect that non-farm income would have a positive effect on household commercialization of the crop. However, this results suggests that households who earn more income from non-farm activities had lower HCIs than those who earned less income from non-farm activities. This may result from the fact that the former group of households could pay less attention to wheat production and this could result in less farm output. Thus, such farmers would have less output for the market, thus decreasing their commercialization level.

\section{CONSTRAINTS TO COMMERCIAL PRODUCTION OF WHEAT BY THE RESPONDENTS}

Table 6 is a multiple response table of the perceived barriers to commercial production of wheat by the respondents. The constraints encountered by the farmers in order of importance were: low output price, inadequate credit facilities, lack of production input, high cost of inputs, transportation problem, diseases and pests, and inadequate land. 
FALOLA A., et al.

Table 6. Barriers to commercialization of wheat production by the respondents

\begin{tabular}{llll}
\hline Constraints & *Frequency & Percentage & Rank \\
\hline Transportation problem & 114 & 54.3 & 5 th \\
Low output price & 185 & 88.1 & $1 \mathrm{st}$ \\
Inadequate credit facilities & 156 & 74.3 & 2nd \\
Inadequate land & 109 & 51.9 & 7 th \\
Diseases/pests & 110 & 52.4 & 6 th \\
Lack of production input & 142 & 67.6 & $3 \mathrm{rd}$ \\
High cost of inputs & 127 & 60.5 & 4th \\
\hline
\end{tabular}

Note:* Multiple responses were allowed; Source: Field data 2015

\section{CONCLUSION AND RECOMMENDATIONS}

It can be infered from this study that the current level of household commercialization of wheat production $(54.7 \%)$ is relatively low. The gap of $45.3 \%$ obtained in the study suggests that almost half of the wheat produced by the households is used for household consumption, thus making less available to the public and industrial use. This could explain the reason for the current reliance on massive importation of wheat to meet the demand-supply gap in Nigeria. This study has further revealed that the factors that positively influence household commercialization of wheat production in the study area were farm size, fertilizer, use of farm machinery, access to credit and improved wheat varieties, while the age of household head and non-farm income negatively influenced it. The study also showed that the major constraints to market-oriented production of wheat in the country are low output price, inadequate credit facilities, lack of production inputs, high cost of inputs, transportation problem, diseases/pests and inadequate land.

Based on these findings, therefore, there is the need for concerted effort by the government, non-governmental organizations (NGOs), Ministry of Agriculture and other relevant agencies to encourage high production of wheat in the study area. Thus, relevant policies should be put in place. These should include encouraging young individuals to practice wheat production and making wheatproduction a worthwhile venture for farmers. This may be achieved through provision of inputs such as improved wheat seeds, fertilizer, pesticides, farm machinery, and so on to farmers at no or subsidized rate. Also, banks and other financial institutions should provide the farmers with credit facilities. This should be done on the basis of little or no interest rate. This will enable the farming households to finance and/or expand their wheat farms.

Moreover, measures that will solve transportation problems should be put in place. These should include construction and/or rehabilitation of rural roads and provision of vehicles for transportation of farm produce to urban centres. This will make conveyance of wheat to urban centres where the farmers could have good prices for their output possible.

Considering the socio-economic characterisitcs of the households, there is the need to put measures that will improve the human resources in the region. Such measures should include overhauling the educational status of the wheat farming households in the study area. To this end, government and other development agencies should promote and improve literacy programme among the farming households. This will provide the farmers with the skills which are useful in terms of allocation of inputs and increasing their output. This will in turn have an indirect positive effect on their commercialization levels with time. In the same vein, extension activities should be overhauled in the region. This should be done by making sure that the wheat farming household have adequate access to extension services. This could be through employment of more extension workers and provision of enabling environment for them to discharge their duties effectively. In the same vein, extension service providers should train the farmers on sound techniques that will improve the commercialization level of the farmers. Putting all these measures in place will not only improve household commercialization level of wheat production in the country but also reduce the current overdependence of Nigeria on wheat importation.

\section{REFERENCES}

1. Najafi, A., Wheat production price performance prediction in the Iranian north province. African Journal of Agricultural Research, 9(1), 74 - 79, 2014.

2. Food and Agricultural Organizations. Agricultural commodities: profiles and relevant WTO negotiating issues, 2009. Retrieved from http://www.fao.org/docrep/006/y4343e/y4343 e02.htm\#TopOfPage. 
FALOLA A., et al.

3. Ahmed, F. F., Economics of wheat marketing in Maiduguri metropolis Borno State, Nigeria. The International Journal of Social Sciences and Humanities Invention, 1(1):1-10, 2014.

4. World Bank, Countries by population (Nigeria), 2015. Retrieved from data.worldbank.org/country/nigeria.

5. First Securities Discount House, Nigeria economic outlook: 2013-2017. FSDH Research, 1-14, 2013. Retrieved from http://www.fsdhsecurities.com/Profiles/Curre nt/NIGERIA_ECONOMIC_OUTLOOK_201 3-2017.pdf

6. Adegboye, R.O., Land, agriculture and food security in Nigeria. 3 Faculty of Agriculture Lecture Series, University of Ilorin Feb. 25th, 2004.

7. Food and Agricultural Organization Statistics, $2015 . \quad$ Retrieved from http://www.fao.org/faostat/en/\#data/QC.

8. Okozie, C. A., Effects of agricultural commercialization on production, consumption and nutrition in farm households in Abia State. Unpublished Ph.D Research, Department of Agricultural Economics, Michael Okpara University of Agriculture, Umudike, Pp 244, 2006.

9. Falola, A., Animashaun, J.O. and Olorunfemi, O.D., Determinants of commercial production of rice in rice-producing areas of Kwara State, Nigeria. Albanian Journal of Agricultural Sciences. 13(2):59 - 65, 2014.

10.Pingali, P., From subsistence to commercial production system: The transformation of Asian Agriculture. American Journal of Agricultural Economics, 79(2):628 - 634, 1997.

11.Timmer, C. P., Farmers and markets: The political economy of new paradigms. American Journal of Agricultural Economics, 79(2):621-627, 1997.

12. Omotesho, O. A., Falola, A., Agbonpolor, G., Analysis of sweet potato production in Offa and Oyun Local Government Areas of Kwara State, Nigeria. Benin International Journal of Agricultural Economics and Extension Services, 2(1):67-75, 2012.

13.Canhoto. A. I., Spinks, N. and Rose, S., Management research: Applying the principles, 2015.

14. Smith, S. M., Determining sample size: How to ensure you get the correct sample size. https://success.qualtrics.com/rs/qualtrics/imag es/Determining-Sample-Size.pdf

15. Onyebinama, U. A. U., Economics Incentive and strategies for commercialization of agriculture in Nigeria. African Journal of
Business and Economic Research, 1(2):182 184, 2012.

16. Adedoyin, S. F. Youth and children programme in Nigeria. In: Agricultural Extension in Nigeria: AESON, pp. 251, 2005.

17. Adewale, J. G., Oladejo, J. A. and Ogunniyi, L. T., Economic contribution of farm children to agricultural production in Nigeria: A case study of Ekiti State. Journal of Social Sciences, 10(2):149 - 152, 2005.

18. Adekunle, O. A., Adefalu, L. L., Oladipo, F. O., Adisa, R. S. and Fatoye, A. D., Constraints to youth's involvement in agricultural production in Kwara State, Nigeria. Journal of Agricultural Extension, 13(1):102-108, 2009.

19. Muhammad-Lawal, A., Omotesho, O. A. and Falola, A., Technical efficiency of youth participation in agriculture: A case study of the Youth-in-Agriculture Programme in Ondo State, Southwestern Nigeria. Nigerian Journal of Agriculture, Food and Environment, 5(1):20 - 26, 2009.

20. Falola, A., Ayinde, O. E. and Ojehomon, V.E.T., Economic analysis of rice production among the youths in Kwara State, Nigeria. Albanian Journal of Agricultural Sciences (AJAS). 12(3):503 - 510, 2013.

21. Agwu, A. E., Factors influencing the adoption of improved cowpea technology in Nigeria. Journal of International Agriculture and Extension Education, 11(1):81 - 84, 2004.

22. Daudu, S., Okwoche, V. A. and Adegboye, O. G., Role of youths in agricultural development in Makurdi Local Government Area of Benue State. Journal of Agricultural Extension, 13(2): 107 - 112, 2009.

23. Bello, M., Madza, T. and Saror, S. F., Nigerian youth involvement in rice production: a case study of Lafia Local Government Area, Nasarawa State. Journal of Environmental Issues and Agriculture in Developing Countries, 3(1):88 - 97, 2011

24. Nin, A., Arndt, C., and Precktel, P., Is agricultural productivity in developing countries really shrinking? New evidence using a modified nonparametric approach. Journal of Development Economics, 71:395415, 2003.

25. Mamudu, A. A., Emelia, G. and Samuel, K. D., Adoption of modern agricultural production technologies by farm households in Ghana: What factors influence their decisions? Journal of Biology, Agriculture and Healthcare, 2(3):1 - 13, 2012.

26. Falola, A., Fakayode, S. B. and Ajayi, E. S., Determinants of marketable surplus of maize in Osun State, Nigeria. Savannah Journal of Agriculture, 8(2):38 - 44, 2013. 